\title{
DIE GESAG VAN DIE PREDIKING VAN DIE NT BRIEWE (2)
}

Dr. B. J. de Klerk

\subsection{Petrus}

\subsection{1 'n Verkorte struktuur van 2 Petrus}

Die tema van sy Brief kan soos volg geformuleer word: Herinnering aan die onvervalste waarheid van die evangelie. Die struktuur van die brief sal daarmee saamhang:

\section{A. Inleiding}

I. Herinnering aan algemene waarhede

II. Fundering van die waarheid

a. Petrus se eie getuienis

b. Die profetiese woord as getuienis

III. Vervalsing van die waarheid

IV. Herinnering aan die waarheid van die wederkoms

$$
\begin{aligned}
& (1: 1-2) \\
& (1: 3-15) \\
& 1: 16-21) \\
& (1: 16-18) \\
& (1: 19-21) \\
& (2: 1-22) \\
& (3: 1-18 a) \\
& (3: 18)
\end{aligned}
$$

Die baie strategiese plasing van die gedeelte oor die fundering $(1: 16-$ 21 ), net na die ontvouing van algemene waarhede van die evangelie en skerp teenoor die valse leraars van hoofstuk 2, is genoegsame aanduiding van die belang daarvan.

2.2.2. Gedagte-enhede en gedagtestruktuurontleding van 2 Pt. $1: 16-21$ In die eerste en die laaste deel van hierdie herinneringsgeskrif herinner Petrus sy lesers onderskeidelik aan die gawes van die nuwe lewe en die hemelse bestemming en aan die $\pi \alpha \rho o v \sigma \alpha$. In die twee middelste gedeeltes van die Brief handel hy oor die fundering en vervalsing van die waarheid. Hy begin met die Goddelike $\delta u v a \mu$, wat alles geskenk het. En nou is dit juis opmerklik

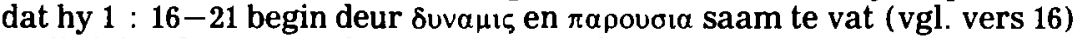
as die inhoud van sy verkondiging. Die hele inhoud van die Brief, van begin

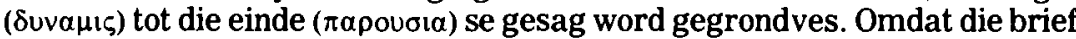
herinnering aan sy verkondiging is, is die verse die fundering van sy hele apostoliese prediking. Die verse staan ook duidelik in teenstelling met dit wat onmiddellik hierna in hoofstuk 2 volg, naamlik die vervalsing van die waarheid. Die perikoop het duidelike gedagteenhede, wat soos volg weergegee kan word:

Bl. 12a.

Uit die rangskikking van die gedagte-eenhede van die perikoop is dit duidelik dat Petrus twee redes aanvoer waarom sy prediking nie fabels is nie, nl. die feit dat hy ooggetuie van die majesteit van God is en omdat hy die profetiese woord as medegetuie het, "wat vas is". Hy brei na elke stelling in omgekeerde orde op een van die twee kardinale begrippe uit.

Die ontleding van die gedagtestruktuur kan ook nog verder meehelp om die klem op die regte plekke te plaas; vgl. skema volgende bladsye.

\subsubsection{Aanskouers van sy heerlikheid (2 Pt. $1: 16-18$ )}

Die herinnering aan die waarhede van die evangelie wat aan hulle verkondig is, en die toekomsverwagting wat as testament van Petrus aan die gemeente verkondig word, het ' $n$ vaste grond. Die lesers moet hieraan vashou omdat die inhoud daarvan nie fabels of legendes is nie maar die feit dat Jesus die Here is (Schelke, $1964:$ 196).

As die verse 17 en 18 as 'n kleiner gedagte-eenheid geneem word, is dit opmerklik dat die brandpunt in die struktuur op die inhoud van die stem 


\begin{tabular}{|c|c|c|}
\hline GEDAGTE-EENHEDE & VERSE & AFRIKAANSE VERTALING \\
\hline $\begin{array}{l}\text { Samevattende } \\
\text { proklamering } \\
\text { van sy gesag }\end{array}$ & $\begin{array}{c}16 a \\
b\end{array}$ & $\begin{array}{l}\text { Want ons het nie kunstig verdigte } \\
\text { fabels nagevolg } \\
\text { toe ons julle die krag en koms van } \\
\text { onse Here Jesus Christus bekendge- } \\
\text { maak het nie, }\end{array}$ \\
\hline $\begin{array}{l}\text { Fundering van } \\
\text { gesag op apos- } \\
\text { toliese woord } \\
\text { (oog en oor) }\end{array}$ & c & $\begin{array}{l}\text { maar ons was aanskouers van sy } \\
\text { majesteit }\end{array}$ \\
\hline $\begin{array}{l}\text { Uitbreiding op } \\
\text { sy majesteit }\end{array}$ & $\begin{array}{l}17 \mathrm{a} \\
\mathrm{b} \\
\mathrm{c}\end{array}$ & $\begin{array}{l}\text { want Hy het van God eer en heerlik- } \\
\text { heid ontvang } \\
\text { toe hierdie stem uit die luisterryke } \\
\text { heerlikheid tot Hom gekom het. } \\
\text { Dit is my geliefde Seun in wie Ek 'n } \\
\text { welbehae het. }\end{array}$ \\
\hline $\begin{array}{l}\text { Uitbreiding op } \\
\text { aanskouers }\end{array}$ & $18 a$ & $\begin{array}{l}\text { En hierdie stem het ons uit die } \\
\text { hemel hoor kom } \\
\text { toe ons saam met Hom op die heilige } \\
\text { berg was. }\end{array}$ \\
\hline $\begin{array}{l}\text { Fundering van } \\
\text { gesag op die } \\
\text { profetiese woord }\end{array}$ & $19 a$ & $\begin{array}{l}\text { En ons het die profetiese woord wat } \\
\text { baie vas is }\end{array}$ \\
\hline $\begin{array}{l}\text { Uitbreiding op } \\
\text { die vastigheid } \\
\text { van die woord }\end{array}$ & $19 b$ & $\begin{array}{l}\text { waarop julle tog moet ag gee } \\
\text { soos op 'n lamp wat in 'n donker plek skyn } \\
\text { totdat die dag aanbreek en die môre- } \\
\text { ster opgaan in julle harte }\end{array}$ \\
\hline $\begin{array}{l}\text { Uitbreiding op } \\
\text { die aard van } \\
\text { die profetiese } \\
\text { woord }\end{array}$ & $\begin{array}{r}20 a \\
b \\
21 a \\
b\end{array}$ & $\begin{array}{l}\text { terwyl julle veral dit moet weet } \\
\text { dat geen profesie van die Skrif ' } n \\
\text { saak van eie uitlegging is nie } \\
\text { want geen profesie is ooit deur die } \\
\text { wil van 'n mens voortgebring nie } \\
\text { maar deur die Heilige Gees gedrywe } \\
\text { het die mense van God gespreek. }\end{array}$ \\
\hline
\end{tabular}




\begin{tabular}{|c|c|c|c|c|}
\hline \multicolumn{3}{|c|}{ GEDAGTE-EENHEDE } & VERSE & GRIEKSE TEKS \\
\hline 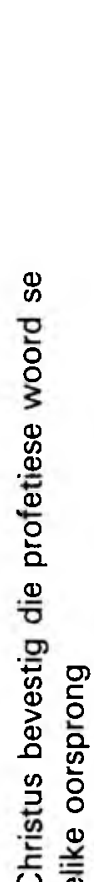 & 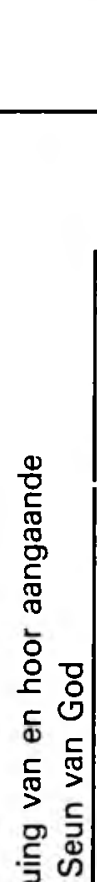 & $\begin{array}{l}\$ \\
\$ \\
\$ \\
\$ \\
\$ \\
\$ \\
\$ \\
\$ \\
\$ \\
\$ \\
\$\end{array}$ & $\begin{array}{r}---- \\
17 a\end{array}$ & 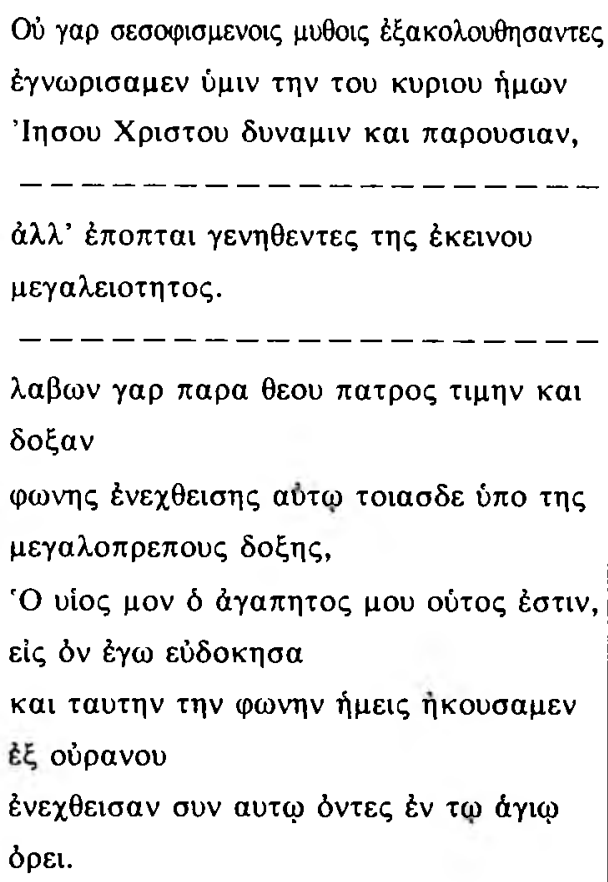 \\
\hline 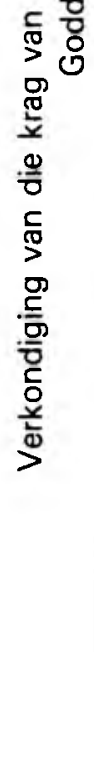 & 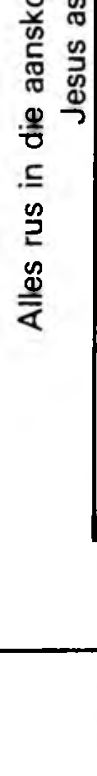 & : & $\begin{array}{l}\text { b } \\
\text { c } \\
\text { d }\end{array}$ & 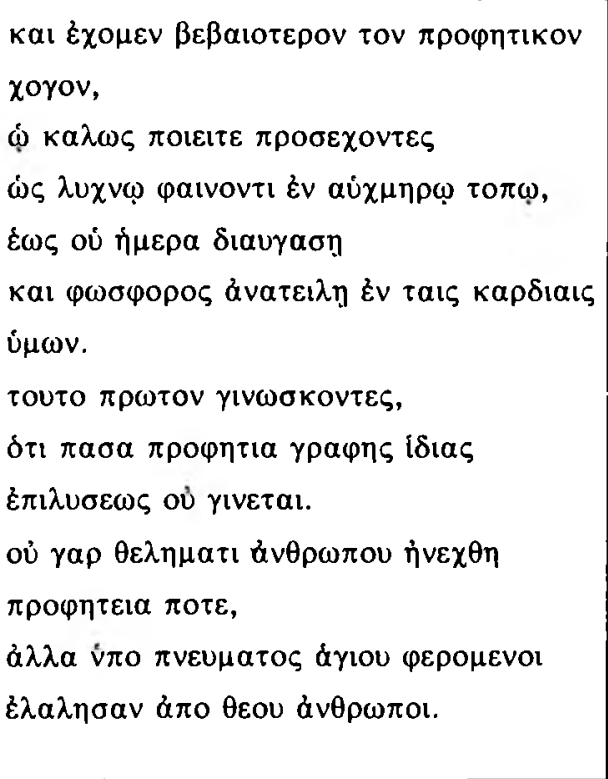 \\
\hline
\end{tabular}


uit die hemel saamgetrek word, naamlik "dit is my geliefde Seun". Deur die daad van die verheerliking en die woord wat hulle hoor, laat God die Here Jesus sien en ken as meer as 'n mens, as sy enigste Seun, wat ook eenmaal in die volle Goddelike heerlikheid voor elkeen geopenbaar sal word.

Petrus was dus teenwoordig toe Christus deur die stem uit die hemel as die Seun van God geopenbaar is. Dit was die bevestiging van wat hulle in soveel wonders gesien het. Uiteindelik is die waarheid in die opstanding deur sy Goddelike krag onderstreep (Calvyn, 1963 : 338). Die konkrete openbaring in die getuienis van die Vader self weerlê dus die aanklag dat Petrus se prediking ' $n$ mite sou wees. Deur die sien van die heerlikheid en die hoor van die stem op die berg word Petrus en sy metgeselle getuies, en dit dien as waarborg vir die verkondiging aan die gemeente.

Die eerste grond vir Petrus se oortuiging dat hy die krag en koms van Christus, dus die hele evangelie, gesaghebbend bekend gemaak het, is die feit dat hy oog-en oorgetuie was van die geweldige waarheid dat Jesus die Seun van God is.

2.2.4 Bevestiging van die profesie (2 Pt. $1: 19-21$ )

Die gedagtegang oor die aanskouing van die heerlikheid van Christus word in vers 18 afgesluit, en dit is daarom baie onwaarskynlik dat kat in vers 19 net by die gebeure wat in vers 18 beskryf word, aansluit. Kal sluit eerder aan by alles wat van vers $16 \mathrm{c}$ (na $\dot{\alpha} \lambda \lambda \alpha$ ) tot aan die einde van vers 18 gesê word en is dus 'n bykomende motivering vir die stelling dat Petrus sy evangelie gesaghebbend bekendgemaak het.

Die verheerliking op die berg is die bevestiging dat Jesus die Seun van God is, en die feit dat God sy Seun na hierdie wêreld gestuur het, is die vervulling van die profesie. Die gebeure waarvan Petrus 'n ooggetuie was, laat die waarheid van God se belofte baie duidelik aan die lig tree. Die stem van God uit die hemel bevestig die woord wat Hy lank tevore gespreek het, en Petrus is nou nog meer van die waarheid van die profetiese woord oortuig en (ook) daarvan dat die profesie die Woord van God is. Juis daarom moet die lesers op die profetiese woord ag gee, want die aanvanklike of voorlopige vervulling in die verheerliking op die berg waarborg die algehele verwerkliking van die belofte van die profete.

In vers 20 en 21 (vgl. Louw, $1965: 202-212$ ) word die tipiese omgekeerde parallelisme as struktuur gevolg, naamlik (a) dit moet julle veral weet (b) dat geen profesie van die Skrif 'n saak van eie uitlegging is nie -, (b) want geen profesie is ooit deur die wil van 'n mens voortgebring nie - (a) maar deur die Heilige Gees gedrywe, het die mense van God gespreek. Die twee negatiewe (b-b) word met die groot ware positief omraam. Die eerste negatief handel oor uitlegging en die tweede maak 'n oorgang na die oorsprong van die profesie, wat dan baie kragtig met die positiewe uitgebou word. Die positiewe kant van eie uitlegging (die eerste negatiewe stelling) word ook met die laaste deel van die sin gestel. Alle willekeurige, eiemagtige uitlegging van die profesie na eie denke en wense, sonder die verligting en leiding van die Heilige Gees, word hiermee veroordeel.

Die rede hiervoor lè in die oorsprong van die profesie, wat nie 'n produk van menslike denke is nie maar uit Goddelike inisiatief spruit. God se Heilige Gees was in die profete werksaam, wat nie beteken dat die menslikheid van die profete ontken word nie, maar hulle was deur die Heilige Gees bestraal en bestier. Hulle word gedrywe, nie so dat hulle buite hulleself was nie (die

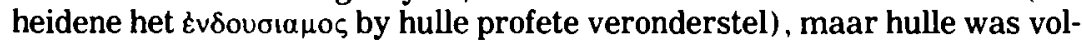


kome onder beheer van die Heilige Gees, in gehoorsaamheid aan die leiding van die Gees. En omdat die profesie deur die Heilige Grees ingegee is, kan dit ook slegs deur die besondere hulp van die Heilige Gees verstaan en verklaar word (Calvyn, 1963:344).

Hier word dus onomwonde verklaar dat die Ou Testament volgens oorsprong, inhoud en vorm geheel en al bepaal word deur en die produk is van die Heilige Gees, hoewel dit deur menslike skrywe tot ons beskikking gekom het (Greijdanus, $1929: 283$ ). Petrus skryf dus 2 Pt. $1: 16-21$ om te verseker dat die waarheid van die evangelie in die algemeen $(1: 3-11)$ en die waarheid van die wederkoms betroubaar oorgedra en gelowig aangeneem word, omdat hy self die majesteit van God gesien het en God se stem en woord op die berg gehoor het. So word ook die profetiese woord bevestig, en omdat die woord deur God se Gees voortgebring is, moet die profetiese woord in ooreenstemming met sy oorsprong uitgelê word.

Die afhanklikheid van die profete word baie duidelik aangedui, want die Gees het hulle nie net geinspireer om te begin praat nie, maar hulle dwarsdeur die prediking voortdurend beheer en gestuur.

'n Belangrike vraag wat in 2 Tim. $3: 16$ en in 2 Pt. $1: 19-21$ beantwoord word, is of die apostoliese prediking ook ingesluit word as die skrywer van die inspirasie of drywing van die Heilige Gees praat. Dit word nie in een van die gedeeltes eksplisiet gesê nie, maar dit word by albei veronderstel.

In $2 \mathrm{Pt}$. 1: 19 en $3: 2$ vind ook 'n baie noue koppeling deur ka plaas en is die intieme band tussen apostoliese prediking en profetiese woord baie opsigtelik. Hieruit kan dan afgelei word dat die apostoliese prediking net soos die profetiese woord deur die Heilige Gees ingegee is. Dit is van betekenis om op te merk dat 2 Timoteus en 2 Petrus as die geestelike testament van Paulus en Petrus onderskeidelik beskou word en dat die waarheid van die inspirasie deur die Heilige Gees juis in die geskrifte voorkom.

2.2.5 Gevolgtrekkings uit 2 Petrus

2.2.5.1 Petrus grond sy gesag op die feit dat sy prediking voorsetting en uitbouing is van dié van die profete ( $1 \mathrm{Pt} .1: 10,11 ; 2 \mathrm{Pt} .1: 19-21)$, wie se gesag vasstaan. Hy beklemtoon die eenheid tussen die twee predikings wat dieselfde boodskap oordra, $\mathrm{nl}$. dat Christus gelyk het en verheerlik is (kyk 1 Pt. 1 : 11 en $5: 1$ ).

2.2.5.2 Sy gesag rus ook op die waarheid dat dié wat die evangelie verkondig het, dit in die Heilige Gees gedoen het ( $1 \mathrm{Pt} .1: 12)$, waarmee hy sê dat die Heilige Gees die apostels tot en gedurende hulle prediking beheers, gestuur en geinspireer het. Ook omdat sy prediking op dieselfde vlak is en voortsetting is van dié van die profete en laasgenoemdes deur die Gees gedrywe is ( $2 \mathrm{Pt} .1: 19)$, geinspireer is (vgl. $2 \mathrm{Tm} .3: 16)$, kan afgelei word dat die Gees die Outeur van sy prediking is.

2.2.5.3 Petrus is 'n oog-en oorgetuie van die optrede, lyding en verheerliking van Christus. Hy is daarom ' $n$ betroubare getuie van dit wat Christus gedoen het en van wat met Hom gebeur het.

2.2.5.4 Baie belangrik van sy waarneming as oog- en oorgetuie is dat hy Christus se heerlikheid aanskou het. Hy het van God uit die hemel gehoor dat Christus die Seun van God is; hy het gesien en gehoor in Christus se doop, lyde en verheerliking dat Hy die Seun is wat die Vader openbaar. Sy gesag rus nie net op die feit dat hy tydens die lewe van Christus op die toneel was nie, maar dat hy die gebeure as openbaring van Jesus as die Seun van God waargeneem het. 


\subsection{Johannes}

2.3.1 'n Verkorte struktuur van 1 Johannes

Die Johannese geskrifte, waaronder 1 Johannes, ontstaan tussen 85 en 95 n.c. (vgl. Coetzee, $1973: 16-18$ ) en is dus die laaste geskrifte van die Nuwe Testament. Dit is daarom belangrik om vas te stel waarop hierdie skrywer hom vir sy gesaghebbende skrywe beroep. Dit is ook duidelik dat die geskrif nie soos die ander Briewe met 'n selfbekendstelling, 'n noem van die geadresseerdes en 'n seëngroet begin nie. Daarom is dit nodig om die geskrif, wat waarskynlik 'n literêre aard het wat van dié van die ander Briewe verskil en tog deel van die ontvouingsprediking vorm, in hierdie ondersoek te betrek.

Die tema is: Ons weet vir seker dat ons die ewige lewe in Jesus Christus, die Seun van God, het. (Ek volg hierin Coetzee, $1980: 16-20$ ).

A. Inleiding

a. Die apostels is oog- en oorgetuies

$(1: 1-4)$

b. Die inhoud van hulle getuienis

$(1: 1,3)$

c. Die waarde van hulle getuienis

$(1: 1)$

$(: 2-4)$

I. Ons is seker van die ewige lewe

II. Ons is kinders van God - daarom weet ons dat ons uit die dood na die lewe verhuis het

$(2: 28-4: 6)$

III. God se liefde is die vaste fondament waarop ons sekerheid van die ewige lewe rus

$(4: 7-5: 5)$

IV. God, die Gees, is self die Getuie dat ons

in die Seun die ewige lewe het

$(5: 6-12)$

a. Die Gees is dié Een wat getuig

b. Die getuienis van Jesus se lewe en werk en dié van die Gees is eenstemmig

$(5: 6)$

c. Die getuienis is dus die getuienis van God self

$(5: 6-8)$

d. God se getuienis: wie die Seun het het die ewige lewe $(5: 11-12)$

B. Slot

a. Die doel en kern van die preek

$(5: 13-21)$

$(5: 13)$

b. Die vrugte van ons geloofsekerheid

$(5: 14-21)$

Die vierde deel, wat ook die klimaks van die preek bevat, is ten volle op die fundering van sy gesag toegespits.

2.3.2 Gedagtestruktuurontleding van $1 \mathrm{Jn} .5$ : 6-12 (ek volg hierin Coetzee, 1981 : 46-47: Vgl. Du Rand 1981 : 3 e.v.) Vergelyk skema volgende bladsy

\subsubsection{Samevatting van $1 \mathrm{Jn} .5: 6-12$}

Deur gebruikmaking van die spiraalstruktuur gebruik Johannes hoofstuk $4: 12-15$ as 'n voorspel tot die klimaks van sy preek waarin die plek van die Heilige Gees in die fundering van sy gesag in baie duidelike taal uitgespel word. Die werk van die Gees in hierdie verband word reeds in $4: 12-15$ genoem. So is die perikoop $5: 6-12$ ook in baie noue aansluiting by $1: 1-4$ deur die uitbouing van die "getuig"- en die "lewe"-motief en deur herhaling

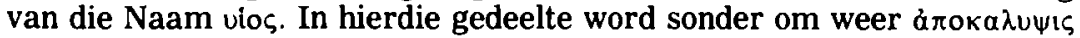
te noem baie pertinent oor die inhoud van die openbaring dat Jesus die Lewe is, gehandel. Uit die gedagtestruktuurontleding is 'n duidelike ringkomposisie aangedui wat die inhoud van die getuienis (buitenste sirkel), die eenstemmigheid van die getuies (as wentelpunt) en die eintlike Getuie (as die mees uitgebreide en deurslaggewende deel) bevat.

By die inhoud van die getuienis gaan dit om die identiteit van die Here Jesus, wat sowel deur die water as die bloed gekom het. Die doop en dood 


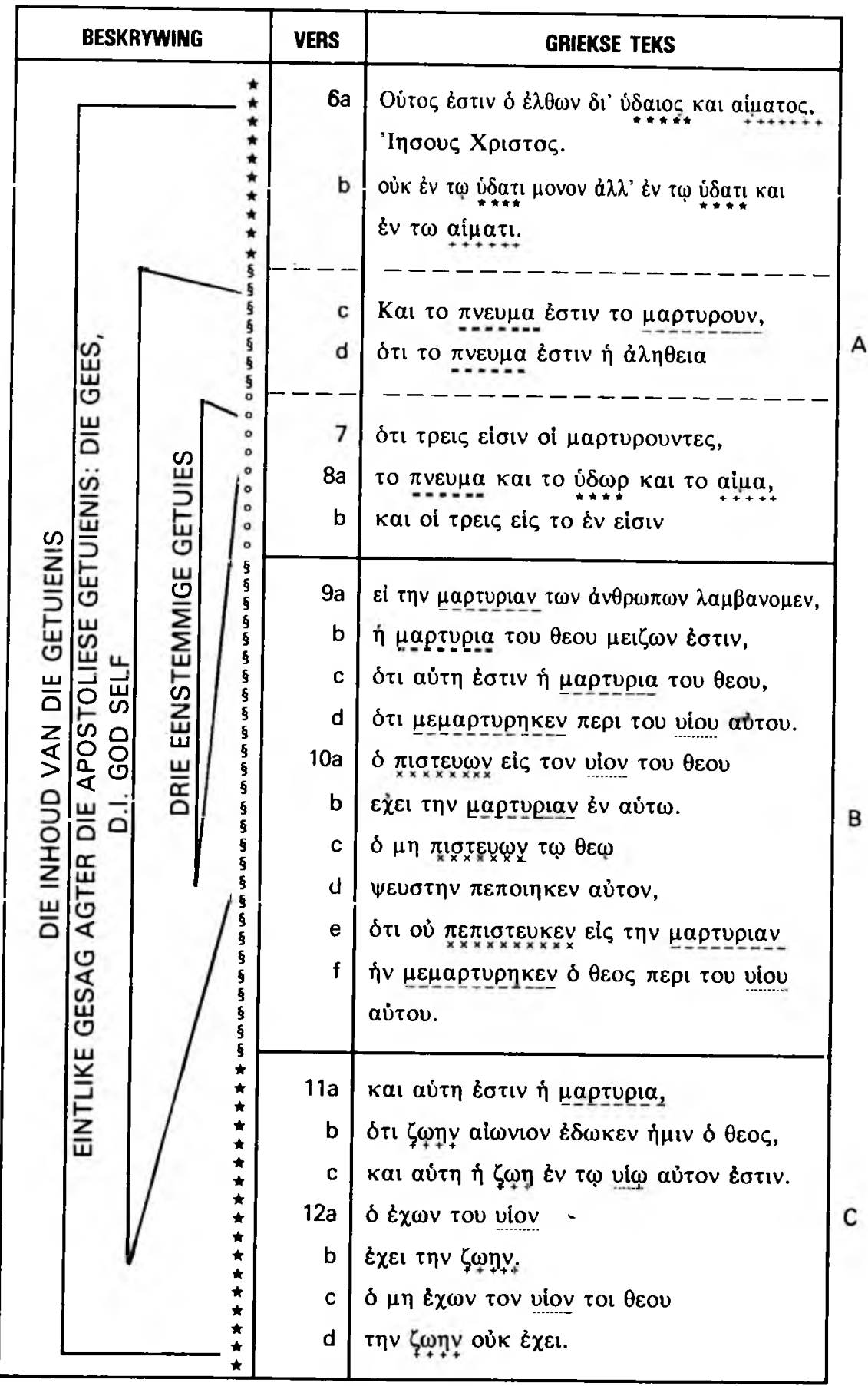


vat Jesus se werk in sy totale omvang (van begin: doop, tot einde: dood) saam en stel ook die beslissende feit van sy vleeswording bo alle twyfel. Dit korrespondeer geheel en al met die getuienis wat in $1: 1-3$ genoem word, en so word die getuienis van die apostels identies gestel met die getuienis van dié wat in $5: 6-12$ getuig. Die feit dat drie getuies hier genoem word, laat die getuienis, volgens die Ou Testament, onweerlegbaar vasstaan. Die Gees word eerste genoem, want Hy getuig self deur onder andere die water en die bloed wat twee aspekte van die Gees se getuienis is. Die drie getuies funksioneer as ' $n$ eenheid en is in volle ooreenstemming met mekaar, maar die Gees is die eintlike Getuie. Daarom word daar reeds in vers 6 van die Gees los van die water en die bloed as die Getuie gepraat.

In hierdie gedeelte word die vierde ei $\mu$-stelling, wat saam met die ander

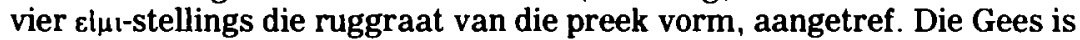
die Een deur wie God self sy altyd geeldende getuienis lewer. Johannes gebruik die lidwoord $\delta$ ( $\mu$ aprupouv) om die oortreffende karakter van hierdie getuienis aan te dui. Die Gees kan die Getuie wees omdat Hy die Waarheid in eie Persoon is. Juis daarom moet sy getuienis onvoorwaardelik geglo word en is sy getuienis beslissend.

Deur die verbinding van vers 6 met vers 9 en 10 in die ringkomposisie

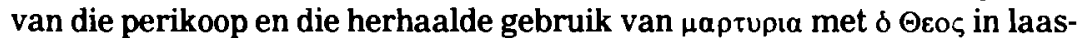
genoemde twee verse word die getuienis van die Gees die getuienis van God genoem. So word God self aangewys as die eintlike gesag agter die apostoliese getuienis. Vers 9 en 10 vorm 'n ingewikkelde parallelisme waarvan vers 10 'n uitbreiding op vers 9 is. Die getuienis is Goddelik en vereis gelowige aanvaarding. God het getuienis gelewer, en sy getuienis is steeds fundamenteel; en die rede waarom die getuienis van die Gees, water en bloed eenstemmig is, is dat God dit self deur die Gees, water en bloed getuig. Die perfektum van die werkwoorde waarvan God die subjek is, stel dat die getuienis vandag nog bo alle twyfel geldig is. Daarom praat Johannes dadelik van geloof en stel deur sy strukturele samestelling van vers 9 en 10 die ondenkbaarheid daarvan dat God deur ongeloof in sy getuienis 'n leuenaar gemaak kan word. Die sonde van ongeloof aangaande die Seunskap van Jesus word in baie duidelike terme uitgespel.

Wat Johannes dus in hierdie deel doen, is om die getuienis aangaande Jesus as Seun van God op die vaste grond te plaas: dit is die Gees wat dit getuig, dit is God self wat dit getuig, en wie dit nie glo nie, gaan so ver om God tot leuenaar te maak.

\subsubsection{Gevolgtrekkings uit 1 Johannes}

2.3.4.1 Met baie groot klem, as die klimaks van die eìı-stellings sê Johannes dat dit die Gees is wat getuig. Hy fundeer sy gesag hiermee op niemand minder as die Heilige Gees nie. Die Gees is die Waarheid, en daarom is sy prediking volkome betroubaar.

2.3.4.2 Die Gees getuig aangaande Christus teenoor die dissipels wat Hom gesien, gehoor en getas het. Dit kan alleen omdat die Lewe wat in God se teenwoordigheid is en was, geopenbaar is, vlees geword het. So fundeer Johannes sy gesag in die openbaring van God.

2.3.4.3 Verlig deur die Gees kon Johannes die Lewe wat in die vlees verskyn het, sien, hoor en tas maar alleen deur die werking van die Heilige Gees as die Lewe herken. Dit maak egter geen afbreuk aan die werklikheid van die waarneming nie, en daarom grond Johannes ook sy gesag in die feit dat hy ooggetuie van die openbaring van God is. 
2.3.4.4 Johannes fundeer sy gesag nie uitdruklik op sy roeping en aanstelling as apostel nie, en sy enigste aanspraak op gesag is nie dat hy in die apostelamp staan nie. Hy laat die waarde van sy aanstelling in sy opdrag blyk en verbind dit baie nou met die feit dat hy oog-en oorgetuie en die Heilige Gees die eintlike Getuie is.

2.4 Gemeenskaplike begronding van die gesag in die Briewe

Sonder om 'n volgorde van belangrikheid te probeer skep kan as samevatting puntsgewys vyf belangrike gronde vir die gesag van die Nuwe-Testamentiese briewe gestel word.

2.4.1 Die skrywers grond hulle gesaghebbende prediking daarin dat die Heilige Gees in en deur hulle getuig en dat Hy die eintlike Getuie is.

2.4.2 Die prediking kan alleeil gesaghebbend wees omdat elkeen van die skrywers 'n openbaring ontvang het. Alleen omdat God Homself openbaar, deur die vleeswording van die Seun of deur die verskyning van die verheerlikte Christus aan hulle, kan hulle met gesag preek.

2.4.3 Uit die openbaring volg dat die skrywers hulle vir hulle gesag beroep op die feit dat hulle oog-en oorgetuie is of dat hulle die verheerlikte Christus gesien en gehoor het. Die gesag rus nie bloot op waarneming nie maar daarop dat hulle verlig deur die Gees, kon verstaan dat Jesus, die Christus, die Seun van God is. Daarom is dit veral die sentrale feit van sy opstanding wat in die dele oor die fundering van sy gesag gevind word. Verder rus hulle gesag ook op hulle baie intieme gemeenskap met Christus.

2.4.4 Die aanstelling deur en opdrag van Christus is ook ' $n$ belangrike oorsprong van die gesag van hierdie skrywers. Selfs die skrywers wat nie op apostelskap aanspraak maak nie, toon die bewussyn dat hulle onder opdrag van Christus skrywe deur hulleself "diensknegte" van Christus te noem. 2.4.5 Die kontinuïteit tussen die prediking van die Briewe en dié van die Ou Testament is 'n verdere grond vir die gesag van die Briewe. Wat dus uit hierdie twee hoofstukke baie duidelik is, is dat die skrywers van die Briewe, wat elkeen op gesag aanspraak maak, hulle gesag baie deeglik fundeer.

3. Die aard van die Gesag

Daar is gepoog om tot die aard, karakter en wese van die gesag deur te dring. Sê die skrywers self iets daaroor en kan dit nagespeur en geformuleer word. Kan afleidings uit die doel en karakter van die geskrif gemaak word of ook uit die strukturele plek in die brief waar die skrywer hom hieroor uitspreek?

3.11 Korintièrs $1: 17-31$.

In hierdie brief waarin Paulus op gesaghebbende wyse verkeerdhede moet regstel en knellende vraagstukke moet oplos, noem hy van die begin af uitdruklik sy Gesagsbron. Hy is nie 'n selfaangestelde indringer nie, maar 'n geroepe apostel van Jesus Christus deur die wil van God.

3.1.1 Gedagtestruktuurontleding van $1: 17-25$

Drie prominente motiewe in hierdie gedeelte is: (i) die wysheid-dwaasheid (Ellis, 1975 : 109-128; Clark, 1972 : 197-205), (ii) die krag-swakheid en (iii) die kruis-gekruisigde-motief en Paulus gebruik dit deur onder andere skerp teenstellings tussen God en wêreld (vers 20,21 ) en God en mens (vers 25) te maak.

Vergelyk die skema volgende bladsy.

3.1.2 Gedagtestruktuurontleding van $1: 26-31$ (as voorbeeld van die krag van God in werking). Vergelyk die skema op bladsy 28. 


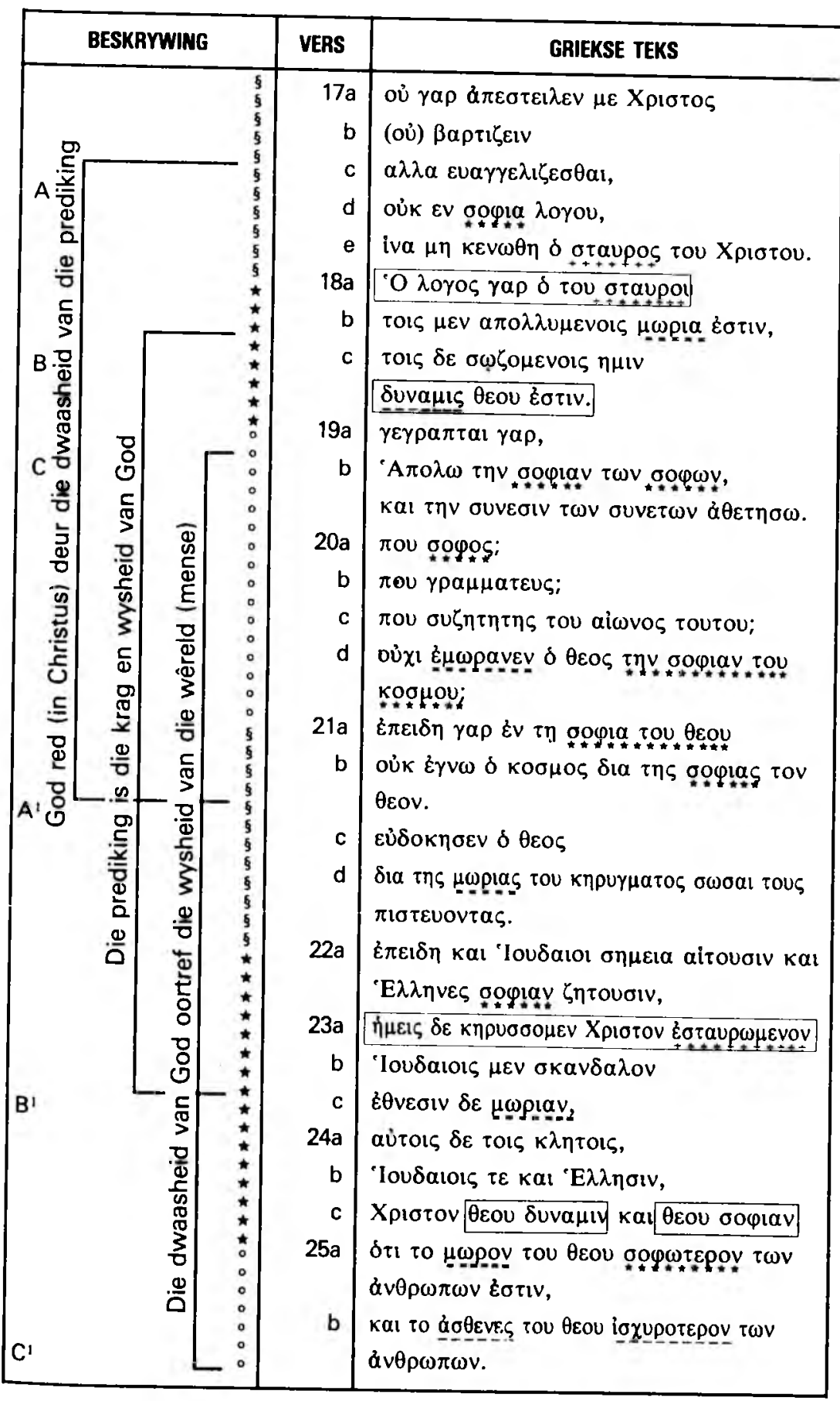




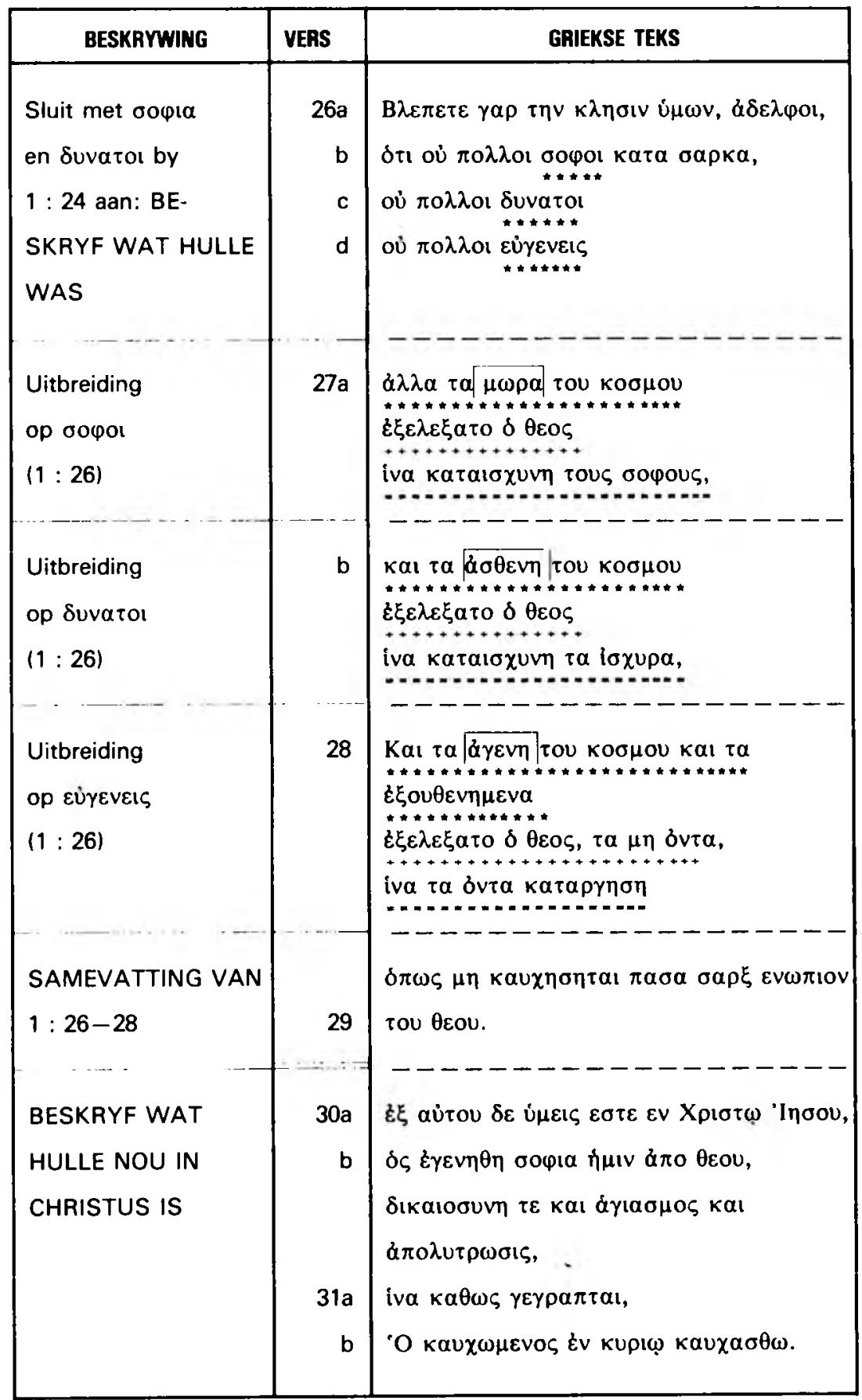




\subsubsection{Samevatting van 1 Kor. $1: 17-31$}

Op baie kernagtige wyse stel die "geroepe apostel volgens die wil van God" in die eerste verse van die brief sy gesag, veral die fundering daarvan, bo alle twyfel vas. In die openingsverse (1:1-9) dui Paulus alreeds die beheersende plek van Christus, in wie se krag hy die gemeente ontmoet, as die kupıs aan. Dit gaan in hierdie deel oor die vermaning van die gemeente om eensgesind te wees.

Die perikoop (1:17-25) het die struktuur van 'n uitgebreide parallelisme waarin die tweede deel $(1: 21-25)$ voortbou op dit wat in die eerste $(1: 17-20)$ gesê is. Die drie dele van vers $17-20$, wat net so in vers $21-25$ herhaal en uitgebrei word, is: God red deur die "dwaasheid van die prediking"; want die prediking is die krag en wysheid van God; daarom oortref die "dwaasheid van die prediking" die wysheid van die mense. Die hoofgedagte van die perikoop lê in vers 18 (herhaal in vers 23,24 ) nl. dat die evangelie die krag en die wysheid van God is.

Christus het Paulus 'n unieke plek in die openbaringsgeskiedenis gegee om spesifiek sendingprediking te verrig, en wanneer Paulus die evangelie onder heidene verkondig maak hy nie van die bestaande wysheidstegnieke of filosofiese inhoude gebruik nie, want dit sou die kruis van Christus van sy inhoud beroof. Die kern van sy prediking was die verkondiging van die gekruisigde Christus as die enigste grondslag vir redding. Dit het God behaag om Hom deur die dwaasheid van die prediking te openbaar en nie deur die instrumente van menslike wysheid, geleerdheid en insig nie.

Die prediking, die evangelie, die woord van die kruis, moet dus 'n besondere karakter of aard besit. Omdat die boodskap van die kruis 'n skeidende werking het, want sommige gaan daardeur verlore en ander word gered, moet dit krag besit. Paulus noem die evangelie die krag van God, wat beteken dat die apostoliese prediking in staat is om lewensverandering by mense te bewerk. Die evangelie word in 'n wêreld gebring waar mense besonderlik op wysheid gesteld is, want die Grieke soek by Paulus wysheid en die Jode, wat gewoond is dat God ' $n$ teken gee om betroubaarheid te bevestig, vra van hom 'n teken. Maar Paulus leer hulle dat dit God behaag dat hy net Christus as Gekruisigde moet preek. Vir die Jode is 'n gekruisigde Messias 'n godsdienstige onmoontlikheid en absolute dwaalleer en daarom ' $n$ valstrik, en vir die Grieke is die leer van lewensverlies ter wille van lewensbehoud dwaasheid. Maar in die kruis en opstanding van Jesus sit God se kragdaad en wysheid. Omdat dit die inhoud van sy prediking is, is sy prediking die krag en wysheid van God.

Paulus noem ook in Rm. 1 : 16 die evangelie die krag van God tot redding, want die krag gaan van God uit en dit is sy almag wat so aktief besig is om verlossing te bewerk. Dit gaan hierin om God se verlossende optrede veral in die kruis en opstanding van Christus, en omdat die evangelie daarvan 'n proklamasie is, is dit self ook ' $\mathrm{k}$ krag van God. Geloof is die enigste kanaal waardeur hierdie krag van God werk, en die evangelie is juis ' $n$ krag tot redding vir elkeen wat glo, omdat die geregtigheid van God daarin openbaar word. Daardeur alleen kan die mens vonr die regterstoel van God bestaan. Die evangelie bied hierdie geregtigheid as ' $n$ teenwoordige werklikheid aan, en hierin rus die evangelie op die Ou Testament, d.w.s. op Goddelike gesag. 
Vir die wêreld (Jode en Grieke) is God se optrede en veral Christus se kruisdood en die prediking daarvan dwaasheid, maar omdat hierdie prediking tot redding in staat is en die menslike wysheid nie in staat is om God te ken nie, oortref die "dwaasheid van God" (die prediking van die kruis) die wysheid van die mense verreweg en gaan die sg. s'wakheid van die kruisprediking die krag van menslike inspanning en ywer te bowe.

Paulus illustreer ten slotte in $1: 26-31$ die werking van die prediking as die krag en wysheid van God, en die gelowiges te Korinte is self die voorbeeld, want hulle wat dwaas, swak en onaansienlik, ja, voor hulle roeping niks was nie, is nou in Christus, dus met Hom verenig. Hy is vir hulle wysheid, regverdigheid, heiligmaking en verlossing verantwoordelik.

3.2 Gevolgtrekkings t.o.v. die aard van die gesag

3.2.1 Die wese van die gesag van die ontvouingsprediking is daarin dat dit die Woord van God is.

3.2.2 Die aard van die gesag word deur die Inhoud (Christus) van die prediking bepaal, want $\mathrm{Hy}$ is die Woord van God, Hy is die krag en die wysheid van God, $\mathrm{Hy}$ is die voortsetting en vervulling van God se Woord in die $\mathrm{Ou}$ Testament.

3.2.3 Die Heilige Gees bepaal ook die aard van die gesag, want die Gees openbaar die inhoud van die prediking, onderrig die predikers, is kragtig in die prediking teenwoordig en getuig saam met die prediking. So gee die Gees aan die boodskap van die evangelie Goddelike gesag.

3.2.4 Die ontvouingsprediking van die Nuwe Testament is wat gesagsaard betref, gelyk aan die prediking van die Ou Testament, en vanuit hierdie vergelyking moet die ontvouingsprediking ook as die Woord van God gekarakteriseer word. Woord en Gees bepaal die aard van die gesag.

3.2.5 Die ontvouingsprediking van die Nuwe Testament is wat gesagsaard betref, ook gelyk aan die "kerugmatiese, grondleggende" prediking van Jesus in die Nuwe Testament.

4. Gevolgtrekkings t.o.v. die funksionering van die Gesag

Die aard van die prediking word deur die skrywers as die krag en wysheid van God, die lewende en blywende Woord van God beskryf. Die vraag wat logies hierop volg, is hoe hierdie Woord van God op 'n gesaghebbende wyse oorgedra word ... Hoe wend die skrywer sy prediking gesaghebbend aan sodat die Woord van God aan die lesers deurgegee kan word?

4.1 Hou rekening met die tema

In al die geskrifte is dit opmerklik dat die skrywers in die gebruikmaking van hulle gesag terdeë met die doel en tema van die geskrif rekening hou. 4.2 Gesag gebruik om die geloofswaarheid te ontvou

Die gesag word veral gebruik om die baie belangrike en sentrale geloofswaarheid te ontvou, en die ontvouing van die geloofswaarheid is tegelyk die bewys van die feit dat die prediking van die skrywer met gesag aangewend word.

\subsection{Gesag gebruik soos tydstip dit eis}

Die skrywer gebruik sy gesag in ooreenstemming met die eise wat die bepaalde periode van die openbaringsgeskiedenis aan hom stel.

4.4 Gesag gebruik in verbondenheid met Christus

Terwyl die skrywer sy gesag gebruik, doen hy dit in die nouste verbondenheid met sy Sender, Jesus Christus.

5. Gevolgtrekkings t.o.v. die uitwerking van die gesag

Die skrywers hanteer vrae, probleme en misstappe in die gemeentes met 
krag en wysheid en beskryf hulle prediking as bevele van God. Na verloop van jare herinner hulle die lesers met vertroue aan dit wat hulle aanvanklik verkondig het. Deur hulle prediking kan hulle die lesers tot geloofsekerheid lei.

Watter reaksie veroorsaak die prediking by die hoorders of lesers en is dit wat die predikers daarmee beoog?

Alleen omdat die Nuwe-Testamentiese Briewe op dieselfde gesagsgrond gefundeer is, en omdat hulle ontvouingsprediking van die betekenis van die Persoon en werk van Jesus Christus is, kan tot ' $n$ sintese gekom word oor die uitwerking wat die gesag het. Die geskrifte is die éen Woord van God, en dit bly in die prediking van die Briefskrywers die onvervalste Woord van God.

Uitwerking alleen weens fundering, aard en funksionering van gesag Die prediking kan alleen 'n uitwerking hẽ omdat dit gesaghebbend gefundeer is, omdat die Woord lewend en kragtig is en vanweë hierdie besondere aard skeiding bring waar dit ook al tref. Die Woord het weens sy kragtige aard en aanbevelenswaardige funksionering deur die prediking van die apostels 'n onthullende uitwerking. Vanweë die feit dat dit God se Woord is, moet dit een of ander uitwerking by die hoorders hê.

Die uitwerking op predikers self

Die kragtige Woord wat mense verkondig, het 'n uitwerking op die predikers self, want die krag van die Woord bring by hulle die blywende oortuiging dat Grod kragtig in hulle prediking werksaam is.

Uitwerking op die ongehoorsames

Die gesaghebbende prediking het 'n uitwerking op die ongelowige en ongehoorsame hoorders. Die ongeloof en ongehoorsaamheid is nie die gevolg van onkunde nie maar spruit uit 'n hardnekkig en moedswillige ongehoorsaamheid. Dit het die verdere uitwerking dat die hoorders self die kanaal sluit om die geregtigheid van God te ontvang en daarom die ryk beloftes van Christus nie kan beërwe nie. Deur hulle daad van ongelowige en ongehoorsame verwerping van die gesaghebbende prediking verwerp hulle nie maar woorde nie maar God self. God sal hulle ook in die finale oordeel verwerp en uit sy teenwoordigheid ban.

Uitwerking op die gelowiges

Die gesaghebbende prediking het ook 'n uitwerking op die gelowiges. Hulle ontvang die Woord (deur die werking van die Gees) met blydskap en verwelkom dit in hulle binneste en verhinder die ontvangs nie deur eiewillige pratery nie maar is altyd gereed om te luister. Die prediking word geglo. en die geloof kry gestalte in die belydenis of aanroeping van die Naam van die Here Jesus Christus. Dit het weer die uitwerking dat dit as Woord van God wat lewend en kragtig is, erken en anvaar word, want die lesers word daardeur tot lewe gebring. Die Woord bring totale lewensverandering by die hoorders wat navolgers van die Here word, hulle van afgode tot God bekeer, Hom met hulle volle lewe dien en die Here Jesus uit die hemel verwag. So word die hoorders deur die Woord voortdurend 'n kragtige, energieke uitwerking wat in 'n daadkragtige geloofslewe tot uiting kom. Die prediking bring die lesers tot geweldige aktiwiteit, wat bewys lewer van hulle geloof, liefde en hoop. Die uitwerking van die prediking op die gelowige trek in die woord Evepyeıa saam en vind sy klimaks in die doen van dit wat die Woord beveel.

God kry die eer 
In die kringloop van toerusting van die predikers deur God, die oordra van die Woord, wat 'n krag van God is, en in die energieke, kragtige uitwerking van die Woord op die leser kry God die eer en word die profetiese woord bewaarheid dat die Woord van God nie leeg tot Hom terugkeer nie.

6. Finale Gevolgtrekkings

6.1 Die skrywers van die Nuwe-Testamentiese Briewe fundeer hulle gesag daarin dat die Heilige Gees in en deur hulle getuig, dat God Hom aan hulle geopenbaar het deur die vleeswording van die Seun of deur die verskyning van die verheerlikte Christus aan hulle, dat hulle oog- en oorgetuies van die dood en veral opstanding van Christus is, dat hulle intieme gemeenskap met Christus het, dat hulle deur Christus aangestel is, van Hom hulle opdragte ontvang en daarom "diensknegte" van die Here is en dat hulle prediking voortsetting van dié van die Ou Testament en van die van Jesus is. 6.2 Die skrywers toon self die aard van hulle gesag aan: hulle prediking is die Woord van God. Die aard en hulle gesag word deur die inhoud (Christus) bepaal: Hy is die Woord van God, die krag en wysheid van God. Die Heilige Gees, wat self kragtig in die prediking werksaam is, gee aan die boodskap van die evangelie Goddelike gesag. Daarom is die ontvouingsprediking van die Nuwe Testament, wat gesagsaard betref, gelyk aan die prediking van die Ou Testament. Dit het Goddelike gesag, omdat dit gelyk is aan die "Kerugmatiese, grondleggende" prediking van Jesus in die Nuwe Testament.

6.3 Die skrywers gebruik hulle gesag altyd in verbondenheid met Jesus Christus en onder beheersing van die Heilige Gees. Die gesag word veral gebruik om belangrike en sentrale geloofswaarhede te ontvou, en die ontvouing van die geloofswaarhede is tegelyk die bewys van die feit dat die prediking van die skrywer met gesag aangewend word. Die skrywers hou in die gebruikmaking van hulle gesag terdeë met die doel en tema van die geskrif rekening en gebruik hulle gesag in ooreenstemming met die eise wat die bepaalde periode van die openbaringsgeskiedenis aan hulle stel. 6.4 Vanweè die feit dat die prediking van die Briewe God se Woord is, het dit 'n uitwerking by die lesers, meestal 'n onthullende uitwerking. Die uitwerking op die predikers self is dat hulle oortuig is dat God kragtig in hulle prediking werksaam is. Die ongelowiges se moedswillige ongeloof en ongehoorsaamheid word ontbloot. Deur hulle daad van ongeloof en ongehoorsaamheid aan die prediking verwerp hulle nie maar woorde nie, maar God self. God sal hulle ook in die finale oordeel verwerp. Die gelowiges, daarenteen ontvang die Woord met blydskap, is altyd gereed om te luister, glo die prediking en kom tot belydenis. Die prediking bring lewe en algehele lewensverandering by die lesers en hulle word voorbeelde vir ander. Die Woord het ' $n$ kragtige, energieke uitwerking en bring die lesers tot geweldige aktiwiteit. So kry God die eer en word die profetiese woord gewaarheid dat die Woord van God nie leeg tot Hom terugkeer nie.

6.5 Vanuit die benaderingshoek van die Briewe as ontvouingsprediking van Christus se prediking gesien het die Nuwe Testament volstrekte Goddelike gesag. Die Nuwe Testament is die Woord van God wat deur die werking van die Gees mense kan wederbaar, wat as kanon vir die Christelike lewe dien, wat beginsel bevat vir die inrigting van die kerklike lewe en die beoefening van die Teologiese Wetenskap.

7. Terreine vir verdere ondersoek

'n Studie soos hierdie, wat op éen bepaalde aspek van die Nuwe Testamen- 
tiese openbaring toegespits het, het aan enkele ander fasette geraak, en daaruit het sekere ander gesigspunte voortgevloei. Enkele terreine of onderwerpe wat met vrug verder ondersoek kan word, is die volgende:

7.1 Die gesag van die prediking van die boek Openbaring (na die studies onderneem in die Departement Nuwe Testament van die PU vir CHO van De Klerk, 1976 (toegespits op die gesag van die prediking van Jesus, d.w.S. die Evangelies), Rabali, 1981 (toegespits op die Evangelie van Johannes), Venter, 1980 (toegespits op die prediking van Handelinge) en hierdie studie oor die gesag van die Nuwe-Testamentiese Briewe moet volledigheidshalwe nog op Openbaring gekonsentreer word;

7.2 die gesag van die prediking van die Ou Testament (alhoewel die navorser nie 'n Ou Testamenticus is nie, het die noodsaaklikheid van sulke studies vir my duidelik geword. Verskeie studies oor die verskillende soorte geskrifte van die Ou Testament kan vanuit gereformeerde kring waardevolle bydraes tot die vraagstuk van Skrifgesag lewer);

7.3 'n studie op die terrein van die Diakoniologie (wat hermeneutiese, pastorale en kategetiese aspekte aansny) oor die gesag van die bediening van die Woord van God aan die gemeente van vandag;

7.4 'n hermeneutiese studie oor die verband tussen die gesag en die tydgerigte karakter van die Nuwe Testament;

7.5 'n studie wat die implikasies van die Skrifgesagsbeskouing van verskeie moderne Nuwe-Testamentici ontleed;

7.6 'n studie, geillustreer met verskeie Nuwe-Testamentiese gedeeltes, van die waarde van die gedagtestruktuurontledingsmetode (teenoor ander struktuuranalitiese metodes) vir die ondersoek (eksegese) van die Nuwe Testament, en

7.7 'n studie van die tipiese gedagtestruktuurpatrone wat die verskillende skrywers van die Nuwe Testament meestal gebruik.

Gelewer voor GTV Potchefstroom 1984.

\section{BRONNELYS}

BLIGHT, JOHN. 1970. Galatians. A Discussion of St. Paul's Epistle. (Householder Commentaries). London: St. Paul Publications.

BRAATEN, C.E. 1965. How new is the New Hermeneutic? Theology Today $22: 234$.

BURTON, ERNEST DE WITT. 1948. A Critical and Exegetical Commentary on the Epistle to the Galatians. (The International Critical Commentary). Edinburgh: $\mathrm{T} \& \mathrm{~T}$ Clark.

CALVYN, J. 1963. The Epistle of Paul the Apostle to the Hebrews and the First and Second Epistles of St. Peter. Translater: William B. Johnston. Grand Rapids: Eerdmans.

CLARK, G. H. 1972. Wisdom in First Corinthians. Journal of the Evangelical Theological Society 15: $197-205$.

COETZEE, J. C. 1973. Diktaat Kanon van die Ou en Nuwe Testament. Potchefstroom: PU vir CHO.

COETZEE, J. C. 1980. Die Gedagtestruktuur van 1 Johannes. Illustrasie van die belangrikheid van struktuurontleding vir die interpretasie en prediking van die Nuwe Testament. Potchefstroom: PU vir CHO.

COETZEE, J. C., B. J. DE KLERK, L. FLOOR. 1980. Die hermeneutiese van die Skrif met die oog op hedendaagse kerklike-tiese vraagstukke. In die Skriflig 54: 12-26.

DE KLERK, B. J. 1976. Die Gesag van die prediking van Jesus. Verhandeling (Th.M.) Potchefstroom: PU vir CHO

DUNCAN, GEORGE S. 1955. The Epistle of Paul to the Galatians. (The Moffatt New Testament Commentary). London: Hodder and Stroughton.

DU RAND. J. A. 1981. A discourse analysis of 1 John. Neotestamentica 13: 1-42.

ELLIS, E. E. 1975. Weisheit, und Erkenntnis in 1 Korintherbrief. Jesus und Paulus. Festschrift W. G. Krummel zum 70. Geburtstag. Gottingen:Vandenhoeck \& Rupert.

GUTHRIE, DONALD. 1969. Galatians. (The Century Bible). London: Nelson. 
LOUW. J. 1965. Wat wordt in 2 Pert. 1, 20 gesteld? Nederlandse Theologiese Tijdschrift 19 $202-212$.

OEPKE. D. ALBERT. 1964. Der Brief des Paulus an de Galater. (Theologischer Handkommentaar zum Neuen Testament). Berlin: Evangelische Verlagsanstalt.

RABALI, T. C. 1981. The Apostle motif with reference to Christ's apostleship in the Gospel of John. Verhandeling (Th.M.) Potchefstroom: PU vir CHO.

RIDDERBOS, H. 1955. Heilsgeschiedenis en Heilige Schift. Het gezag van het nieue testament. Kampen: Kok.

RIDDERBOS, HERMAN. 1959. Heilsgeschiedenis (Commentaar op het Nieuwe Testament). Kampen : J. H. Kok.

RIDDERBOS, HERMAN N. 1976. The Epistle of Paul to the Churches of Galatia. (The New International Commentary on the New Testament). Grand Rapids: Eerdmans.

SCHUTE, J. H. 1975. Paul and the anatomy of Apostolic Authority Cambridge: University Press.

SNYMAN, W. J. 1977. Nuwe en Ou dinge - Uit die Skat van die Koninkryk. Potchefstroom: Pro Rege.

VAN DER WALT, T. 1974. Die moderne rigting in die Bybelwetenskap (Nuwe Testament). Ongepubliseerde werkstuk: SA Akademie vir wetenskap en kuns.

WOOD. FRED M. 1972. The Glory of Galatians. Nashville: Broadman Press. 